\title{
ALPHA AMYLASE INHIBITORY ACTIVITY OF DIFFERENT EXTRACT OF BARK OF ALBIZIA LEBBECK (L.) BENTH
}

\author{
PRIYANKA JAISWAL ${ }^{*}$, PADMA KUMAR ${ }^{2}$ \\ ${ }^{1,2}$ Laboratory of Plant Tissue Culture and Secondary Metabolites, Department of Botany, University of Rajasthan, Rajasthan, India \\ Email: priyankajaiswal.micro@gmail.com
}

Received: 25 Apr 2017 Revised and Accepted: 19 Jun 2017

\section{ABSTRACT}

Objective: To evaluate the alpha amylase inhibitory activity of different extract of bark of Albizia lebbeck (L.) Benth.

Methods: Bark of A. lebbeck was collected and air dried. Extraction of flavonoid, alkaloid and steroid carried out using standard methods. Extracts in different polar and non polar solvents were extracted using soxhlet method. Filtered extracts were subsequently tested for alpha amylase inhibitory activity using the chromogenic dinitrosalicylic acid (DNSA) method and starch iodine method. Experiments were performed in triplicates for three different sets and mean \pm standard error of the mean was used for calculation. Graphpad prism 5 software was used for one way analysis of variance (ANOVA), linear regression and statistical difference analysis. IC $_{50}$ values were also calculated.

Results: We found that the free flavonoid extract had higher $43.50 \pm 0.17 \%$ to $73.43 \pm 0.08 \%$ inhibition (at a concentration $0.5-1.5 \mathrm{mg} / \mathrm{ml}$ ) with an $\mathrm{IC}_{50}$ value of $0.6653 \mathrm{mg} / \mathrm{ml}$. At the same concentration methanol, water and bound flavonoid extracts also showed good inhibitory activity i.e. $28.63 \pm 0.15 \%$ to $37.50 \pm 0.20 \%, 26.67 \pm 0.12 \%$ to $32.07 \pm 0.17 \%$ and $26.70 \pm 0.15$ to $32.67 \pm 0.12 \%$ with an IC 50 value of $7.3621 \mathrm{mg} / \mathrm{ml}, 22.2844 \mathrm{mg} / \mathrm{ml}$ and $41.6869 \mathrm{mg} / \mathrm{ml}$ respectively.

Conclusion: The prepared free flavonoid, bound flavonoid, water and methanol bark extracts of Albizia lebbeck showed the significant alpha amylase inhibitory activity. Further works is required to identify the bioactive compound responsible for inhibition of alpha amylse enzyme.

Keywords: Amylase, Free flavonoids, Antidiabetic

(C) 2017 The Authors. Published by Innovare Academic Sciences Pvt Ltd. This is an open access article under the CC BY license (http://creativecommons.org/licenses/by/4.0/) DOI: http://dx.doi.org/10.22159/ijpps.2017v9i8.19411

\section{INTRODUCTION}

Diabetes is a serious, chronic disease which occurs either when the production of insulin decreases, or when the insulin produced is not effectively used by the body [1]. Gain in the level of glucose inside the body leads many irregular functioning of the organs like blood vessels damage, heart problems, vision problems, kidney function and nerves. In WHO recent report, it is stated that over 400 million people live with diabetes [2]. Diabetes is of two types i.e. Type 1 diabetes which is also known as insulin-dependent diabetes is occurring due to decrease in the production of insulin in the body. Type 2 diabetes which is otherwise known as non insulin-dependent diabetes is characterized as ineffective use of insulin by the body. The most prevalent type in the world is Type 2 diabetes [1]. Earlier Type 2 diabetes was found in adults but now it is also prevalent among children [2]. According to the recent data on the prevalence of diabetes, the number of diabetes patients is going to high 143 million persons to 300 million persons by 2025 [3]. The researcher showed that the gastro retentive microsphere is useful for delivering repaglinide (RG) for the treatment of non-insulin dependent diabetes mellitus (NIDDM) [4].

People for treatment of diabetes have taken advantage of medicinal plants since time immemorial. All the main active compounds present in medicinal plants which are responsible for the treatment of disease and their mode of action are provided in the encyclopedia. Man depends on plants for all of their needs whether it related to health or uses of daily requirement [5]. The secondary metabolites such as alkaloids, steroids and flavonoids etc. which are produced by the plants has been used by pharma industries at solving many of the issues of human beings. As concerns related to the side effect of different available medicine are rising hence there is a continuous need of research and development of new herbal drugs for the treatment of various diseases found in among human [6].

$\alpha$-amylase is one of the key digestive enzyme which catalyses hydrolysis of starch to maltose in the beginning and at the end convert it to glucose therefore by inhibiting the activity of alpha amylase one can think about the control of diabetes as diabetes is related to increase in glucose level inside body and alpha amylase is responsible for the conversion of starch into many simple sugars like dextrin, maltose and glucose [7]. The activity of alpha amylase is correlated to the elevated postprandial hyperglycemia therefore control of alpha amylase activity becomes significant in the treatment of diabetes [8] Herbal products which consist of many compounds have been used by the people and which has become the dependable source of remedy for various diseases like diabetes. Hence, the discovery of new potential drugs from medicinal plants with fewer side effects for the treatment of diabetes has to be continued.

Albizia lebbeck known as Shirisha in Ayurveda is an important medicinal plant belonging to the family Fabaceae and subfamily Mimosaceae. It is recognized in the Indian subcontinent for its medicinal uses. Bark is dark brown to greenish black. It is utilized in the Indian traditional system as a folk medicine as well to remedy of several diseases like asthma, arthritis and burns [9] Antihyperglycaemic and antidiabetic effect of the leaf extracts of Albizia lebbeck on alloxan and streptozotocin induced diabetic mice has been reported [10]. Studies related to pharmacological activities on bark of this plant are scarce. Its bark extract have been reported to posses' antispermatogenic, antiandrogenic activities in male albino rats [11] and also antioxidant potential [12].

Review of literature reveals that there are no reports showing the comparative alpha amylase inhibitory activity of polar, non-polar, free flavonoids, bound flavonoids, alkaloid and steroid extract of Albizia lebbeck bark. Hence in the present study an attempt was made to evaluate the potential and compare the alpha amylase inhibitory activity of different extracts of Albizia lebbeck bark.

\section{MATERIALS AND METHODS}

\section{Collection of plant material}

Bark of Albizia lebbeck, was collected from the eastern region of Rajasthan i.e. Jaipur. Plant was identified by the senior taxonomist of 
the Department of Botany, University of Rajasthan and Voucher Specimen No: RUBL211460 was submitted to the Herbarium, Department of Botany, University of Rajasthan.

\section{Preliminary phytochemical screening}

The phytochemical analysis to test the presence of alkaloids, flavonoids, steroids in the powdered sample was carried out using standard methods [13-14].

\section{Preparation of extracts}

\section{Flavonoid extraction}

Bark of Albizia lebbeck was collected; shade dried, finely powdered and Subramanian and Nagarjan method was used for extraction of flavonoids [15]. 100 grams of sample with $80 \%$ of hot methanol was soxhlet extracted on a water bath for $24 \mathrm{~h}$ and filtered. The filtrate was re-extracted using separating funnel successively with petroleum ether in the first fraction and ethyl ether in the second fraction, and ethyl acetate in the third fraction. As petroleum ether dissolves fatty substances in it, the fraction of it was discarded, whereas fractions of ethyl ether and ethyl acetate were further analyzed for free and bound flavonoids respectively. The ethyl acetate sample was reflexed with $7 \% \mathrm{H}_{2} \mathrm{SO}_{4}$ for two hours so that hydrolysis removed bounded sugars and again in separating funnel, the filtrate was reflexed with ethyl acetate. To neutralize the obtained filtrate it was washed with distilled water. Thus, the ethyl ether fraction contains free flavonoids and ethyl acetate fractions contain bound flavonoids were dried in vacuo and weighed. The obtained extracts were stored at $4{ }^{\circ} \mathrm{C}$.

\section{Alkaloids extraction}

Alkaloids were extracted from bark of Albizia lebbeck by wellestablished method [16]. Hundred grams of sample were extracted in $20 \mathrm{ml}$ methanol after shaking of 15 min. Filtrate obtained was kept for drying and then the residual mass was treated with $1 \%$ $\mathrm{H}_{2} \mathrm{SO}_{4}$ (5 ml.) for 2 times. After this, extraction was done in $10 \mathrm{ml}$ chloroform using separating funnel. The chloroform layer which was organic by nature was rejected and the other aqueous layer was basified using $30 \% \mathrm{NH}_{4} \mathrm{OH}$ of $\mathrm{pH}=9-10$. Again basified layer was extracted in $10 \mathrm{ml}$ chloroform and organic layer of chloroform which was in a lower position was collected in a flask and the step was repeated with fresh chloroform. Extracts was thus obtained was dried in vacuum for further use.

\section{Steroid extraction}

Steroids were extracted from bark of Albizia lebbeck by wellestablished method [17]. Fine powdered hundred gram of sample of plant bark was extracted in petroleum ether for two to four hours. Then it was filtered and residual mass was treated with $15 \%$ ethanolic $\mathrm{HCl}$ for four hours. Further it was extracted in ethyl acetate and washed with distilled water to neutralize the extract. To remove the moisture content of the neutral extract it was passed over sodium sulphate and was dried in vacuum.

\section{Extraction in different polar and non polar solvents}

Powdered bark of Albizia lebbeck (20g) was taken in three flasks and water, methanol and petroleum ether were used as solvent. The dried material and solvents were taken in a 1:10 ratio. Those were kept at soxhlet unit for complete one day. Obtained extracts were thus filtered and the filtrate was subjected to dry in vacuum to obtain extract. The residual extract that obtained was stored in a refrigerator at $4{ }^{\circ} \mathrm{C}$ in sterile glass bottles.

\section{In vitro alpha amylase inhibitory assay}

\section{Starch iodine assay}

Screening of alpha amylase inhibitors were performed using Xiao et al. method in test tubes with slight modifications based on the starch iodine test [18]. The assay mixture was about $120 \mu \mathrm{l}$ of $0.02 \mathrm{M}$ sodium phosphate buffer ( $\mathrm{pH}$ 6.9), $1.5 \mathrm{ml}$ of salivary alpha amylase and bark extracts at a concentration from 0.5-1.5 $\mathrm{mgml}^{-1}(\mathrm{w} / \mathrm{v})$ was incubated at $37{ }^{\circ} \mathrm{C}$ for $10 \mathrm{~min}$. After that, soluble $1 \%$ starch was added at each reaction mixture and incubated at $37{ }^{\circ} \mathrm{C}$ for $15 \mathrm{~min}$. Then $60 \mu \mathrm{l}$ of $1 \mathrm{M} \mathrm{HCl}$ was added to the reaction mixture to stop the enzymatic reaction and immediately $300 \mu \mathrm{l}$ of iodine reagents was added. If any change in colour was noted and at $620 \mathrm{~nm}$ the absorbance was read. The plant extracts was not added to the control reaction showing 100\% enzyme activity. Extract control was also included to check if any absorbance produced by bark extract. Thus different colour obtained indicates the presence of starch (dark-blue), absence of starch (yellow) and partially degraded starch (brownish) in the reaction mixture. If inhibitor was present in the extract of plant bark it inhibit the degradation of starch added to the enzyme assay mixture and form a dark-blue colour complex whereas no colour showed the absence of inhibitor.

\section{3, 5-dinitrosalicylic acid assay}

The inhibition assay of bark extract of Albizia lebbeck was performed using the chromogenic dinitrosalicylic acid (DNSA) method [19]. The assay mixture consists of $500 \mu \mathrm{l}$ of $0.02 \mathrm{M}$ sodium phosphate buffer (pH 6.9), $1 \mathrm{ml}$ of salivary alpha amylase and $400 \mu \mathrm{l}$ extracts at concentrations from $0.5-1.5 \mathrm{mgml}^{-1}$ were incubated at $37^{\circ} \mathrm{C}$ for 10 min. After pre-incubation, $580 \mu \mathrm{l}$ of $1 \%$ starch solution was added to each tube and incubated at $37{ }^{\circ} \mathrm{C}$ for $15 \mathrm{~min}$. Using $1.0 \mathrm{ml}$ DNSA reagent the reaction was terminated and tubes were placed in boiling water bath for $5 \mathrm{~min}$. After this, cooled to room temperature and at $540 \mathrm{~nm}$ the absorbances were measured. The control did not contain any bark extract represented $100 \%$ enzyme activity. Extract control was also included to check if any absorbance produced by bark extract except for the enzyme.

Formula for calculation of the percent inhibition of alpha amylase:

$$
\begin{gathered}
\% \text { Relative enzyme activity }=\frac{\text { Enzyme activity of test }}{\text { Enzyme activity of control }} \times 100 \\
\begin{array}{r}
\text { Percent Inhibition of the } \alpha \text { amylase activity } \\
=100-\% \text { Relative enzyme activity }
\end{array}
\end{gathered}
$$

\section{Statistical analysis}

Experiments were performed in triplicates for three different sets and mean \pm standard error of the mean was used for calculation. Graphpad prism5 software was used for ANOVA, linear regression and statistical difference analysis. The $\mathrm{IC}_{50}$ values were computed.

\section{RESULTS}

Out of the solvent extracts methanol extract exhibited significant inhibition of alpha amylase activity. Free flavonoids extract of bark showed maximum alpha amylase inhibitory activity as compared to bound flavonoid, alkaloid and steroid extract. Maximum activity of free flavonoids extracts may be due to presence of potential inhibitory compound in extract. Alkaloid, steroid and petroleum ether extracts showed negligible inhibitory activity with insignificant $\mathrm{IC}_{50}$ value.

\section{Extract with maximum inhibitory effect on the alpha amylase activity.}

Free flavonoids extracts (at a concentration $0.5-1.5 \mathrm{mg} / \mathrm{ml}$ ) showed maximum $\alpha$-amylase inhibitory activity from $43.50 \pm 0.17 \%$ to $73.43 \pm 0.08 \%$ with an $\mathrm{IC}_{50}$ value of $0.6653 \mathrm{mg} / \mathrm{ml}$. At the same concentration methanol, water and bound flavonoid extracts also showed good inhibitory activity i.e. $28.63 \pm 0.15 \%$ to $37.50 \pm 0.20 \%$, $26.67 \pm 0.12 \%$ to $32.07 \pm 0.17 \%$ and $26.70 \pm 0.15$ to $32.67 \pm 0.12 \%$ with an $\mathrm{IC}_{50}$ value of $7.3621 \mathrm{mg} / \mathrm{ml}, 22.2844 \mathrm{mg} / \mathrm{ml}$ and $41.6869 \mathrm{mg} / \mathrm{ml}$ respectively (table 1 ).

\section{Extracts with inhibitory effects on the $\alpha$-amylase activity}

Petroleum ether, alkaloid and steroid extracts showed minimum inhibitory activity from $2.67 \pm 0.19 \%$ to $4.9 \pm 0.17 \%, 1.17 \pm 0.07 \%$ to $2.23 \pm 0.03 \%, 1.53 \pm 0.03 \%$ to $2.23 \pm 0.03 \%$ with an IC50 value of $1000 \mathrm{mg} / \mathrm{ml}, 16982.365 \mathrm{mg} / \mathrm{ml}$ and $16982.365 \mathrm{mg} / \mathrm{ml}$ respectively (table 2). 
Table 1: Extract with maximum inhibitory effect

\begin{tabular}{|c|c|c|c|c|c|}
\hline S. No. & Name of extract & Concentration $\mathrm{Mg} / \mathrm{ml}$ & $\%$ inhibition & Regression equation & $\mathrm{IC}_{50}$ value $(\mathrm{mg} / \mathrm{ml})$ \\
\hline \multirow[t]{3}{*}{1} & Free flavonoid & 0.5 & $43.50 \pm 0.17$ & $Y=5.288+1.624 X$ & 0.6653 \\
\hline & & 1.0 & $59.53 \pm 0.12$ & & \\
\hline & & 1.5 & $73.43 \pm 0.08$ & & \\
\hline \multirow[t]{3}{*}{2} & Water & 0.5 & $26.67 \pm 0.12$ & $Y=4.489+0.379 X$ & 22.2844 \\
\hline & & 1.0 & $32.73 \pm 0.18$ & & \\
\hline & & 1.5 & $32.07 \pm 0.17$ & & \\
\hline \multirow[t]{3}{*}{3} & methanol & 0.5 & $28.63 \pm 0.15$ & $Y=4.561+0.507 X$ & 7.3621 \\
\hline & & 1.0 & $32.57 \pm 0.19$ & & \\
\hline & & 1.5 & $37.50 \pm 0.20$ & & \\
\hline \multirow[t]{3}{*}{4} & Bound flavonoid & 0.5 & $26.70 \pm 0.15$ & $Y=4.451+0.339 X$ & 41.6869 \\
\hline & & 1.0 & $28.87 \pm 0.03$ & & \\
\hline & & 1.5 & $32.67 \pm 0.12$ & & \\
\hline
\end{tabular}

Values are given as mean \pm standard error of mean (SEM) $(n=3)$, one way analysis of variance (ANOVA) was used which show significant difference with respect to control $(\mathrm{P}<0.05)$.

Table 2: Extract with insignificant inhibitory effect

\begin{tabular}{|c|c|c|c|c|c|}
\hline S. No. & Name of extract & Concentration $\mathrm{Mg} / \mathrm{ml}$ & $\%$ inhibition & Regression equation & $\mathrm{IC}_{50}$ value $(\mathrm{mg} / \mathrm{ml})$ \\
\hline \multirow[t]{3}{*}{1} & Pet ether & 0.5 & $2.67 \pm 0.19$ & $Y=3.133+0.622 X$ & 1000 \\
\hline & & 1.0 & $3.33 \pm 0.19$ & & \\
\hline & & 1.5 & $4.9 \pm 0.17$ & & \\
\hline \multirow[t]{3}{*}{2} & alkaloid & 0.5 & $1.17 \pm 0.07$ & $Y=2.785+0.524 X$ & 16982.365 \\
\hline & & 1.0 & $1.83 \pm 0.03$ & & \\
\hline & & 1.5 & $2.23 \pm 0.03$ & & \\
\hline \multirow[t]{3}{*}{3} & steroid & 0.5 & $1.53 \pm 0.03$ & $Y=2.785+0.524 X$ & 16982.365 \\
\hline & & 1.0 & $1.83 \pm 0.03$ & & \\
\hline & & 1.5 & $2.23 \pm 0.03$ & & \\
\hline
\end{tabular}

Values are given as mean \pm standard error of mean (SEM) $(n=3)$, one way analysis of variance (ANOVA) was used which show significant difference with respect to control $(\mathrm{P}<0.05)$.

\section{DISCUSSION}

Natural products from plants used for the treatment of diabetes. There has been a continuous search for the development of novel and cost effective drugs from natural sources. A part of A. lebbeck for the treatment of various diseases has been used since ancient times. In many previous studies on its use as antimicrobial [20-21], use of seeds in inflammation, skin diseases, leprosy, leucoderma, chronic catarrh, seminal weakness, opthalmopathy and poisoning has been described [22-23]. The earlier experimental investigations demonstrated that many naturally occurring agents and plant extracts had shown antidiabetic activities [24]. These alpha amylase inhibitors are also called as starch blockers since it prevents or slows the absorption of starch in to the body mainly by blocking the hydrolysis of 1, 4-glycosidic linkages of starch and other oligosaccharides into maltose, maltriose and other simple sugars [25]. Only few studies focused on the antidiabetic activity of Albizia lebbeck extracts and that too without testing for free flavonoid, bound flavonoids, steroids and alkaloids. Though there are reports available on the antidiabetic activity of Albizia lebbeck, but there is no report on antidiabetic activity using salivary alpha amylase of Albizia lebbeck bark. Review of literature showed that very less work has been done on the anti diabetic potential of different bark extract therefore in this study, we compared $\mathrm{IC}_{50}$ value of $\alpha$-amylase inhibitory activity of steroids, free flavonoids, bound flavonoids and alkaloids extracts isolated from the bark of $A$. lebbeck with polar and non polar solvent based extracts. The goal of this work was to develop a potential antidiabetic compounds from the crude extracts of Albizia lebbeck bark. The present study confirmed that the free flavonoid bark extract has a higher antidiabetic activity with the $\mathrm{IC}_{50}$ at $0.6653 \mathrm{mg} / \mathrm{ml}$ when compared to water, methanol and bound flavonoid bark extracts. The petroleum ether, steroid and alkaloid bark extract showed the very less activity with insignificant $\mathrm{IC}_{50}$ value. To find out the mode of action of bark extracts as alpha amylase enzyme inhibitors, further research is required to be continuous so that to qualify the action of different constituents in the extract. The results of this study directs further researches to evaluate the therapeutic potentialities of free flavonoids, methanol, water and bound flavonoids extracts of bark of $A$. lebbeck in the management of diabetes either alone or in a combinatorial therapy.

\section{CONCLUSION}

Diabetes is among the major health problems worldwide. The current available therapies are not of much use in prevention or reduction of disease. Thus, continuous search for new natural product with fewer side effects is the requirement of the period. Results of selected plant extract showed significant antidiabetic properties. We were able to identify promising medicinal plants which could be used for treatment of diabetes. Further chemical isolation of novel molecules and their mode of action are warranted for the elucidation of the activity. Our results justified the use of investigated plants in the Indian ethnomedicine. The present study showed that the bark extract of selected plant exhibited significant inhibition of alpha amylase activity with less $\mathrm{IC}_{50}$ value. These findings support that a number of investigated plants could be a valuable source of new antidiabetic compounds that can potentially deliver novel mechanisms of actions. Hence the extract may be useful as better therapeutic agent especially for the treatment of diabetes. Further studies are warranted to follow our observations.

\section{ACKNOWLEDGEMENT}

The authors are thankful to the Head, Department of Botany, University of Rajasthan, Jaipur and to UGC for financial assistance.

\section{AUTHOR CONTRIBUTION}

Principal author: Performed collection of sample, extraction, analysis, interpreted data, wrote the manuscript and acted as corresponding author.

Co-author contribution: Supervised the development of work and helped in the evaluation of the manuscript.

\section{CONFLICT OF INTERESTS}

There is no conflict of interest 


\section{REFERENCES}

1. Definition, diagnosis and classification of diabetes mellitus and its complications. Part 1: Diagnosis and classification of diabetes mellitus, World Health organization; 1999.

2. Global report on diabetes. World health organization; 2016.

3. Mitra A, Bhattacharya D, Roy S. Dietary influence on type 2 diabetes (NIDDM). J Human Ecol 2007;21:139-47.

4. Kohli S, Sharma M, Pal A. Ethylcellulose floating microspheres of antidiabetic agent: in vitro and in vivo evaluation. Int J Appl Pharm 2017;9:44-9.

5. Keerthana G, Kalaivani MK, Sumathy A. In vitro alpha amylase inhibitory and anti-oxidant activities of ethanolic leaf extract of Croton bonplandianum. Asian J Pharm Clin Res 2013;6 Suppl 4:32-6.

6. Satpal S, Anantha KTH, Subban K, Gini CK, Jinu MV, Chelliah J. Phytomedicinal importance of Saraca asoca (ashoka): an exciting past, an emerging present and a promising future. Curr Sci 2015;109:1790.

7. Alexander R. Maltodextrins: production, properties and applications. In: Schenk F, Hebeda R. ed. Starch hydrolysis products; Worldwide technology: production and applications, New York; 1992. p. 62-122.

8. Eichler HG, Korn A, Gasic S, Prison W, Businger J. The effect of new specific $\alpha$-amylase inhibitor on post-prandial glucose and insulin excursions in normal subjects and type 2 (non-insulin dependent) diabetic patients. Diabetologia 1984;26 Suppl 4:278-81.

9. Faisal M, Singh PP, Irchhariya R. Review on Albizia lebbeck-a potent herbal drug. Int Res J Pharm 2012;3 Suppl 5:63-8.

10. Sengupta R, Sawant CS, Karmarkar SM, Bhagwat AM Antihyperglycaemic and antidiabetic effect of the leaf extracts of Albizzia lebbeck Linn. (Benth) and Psidium guajava Linn. on alloxan and streptozotocin induced diabetic Mice. Asian J Pharm Clin Res 2011;4 Suppl 1:129-31.

11. Gupta RS, Kachhawa JBS, Chaudhary R. Antispermatogenic, antiandrogenic activities of Albizia lebbeck (L.) Benth bark extract in male albino rats. Phytomed 2006;13:277-83.

12. Resmi CR, Venukumar MR, Latha MS. Antioxidant activity of Albizzia lebbeck in alloxan diabetic rats. Indian J Physiol Pharmacol 2006;50 Suppl 3:297-302.
13. Harborne JB. Phytochemicals methods. Chapman and Hall, New York; 1973. p. 95-120.

14. Trease GE, Evans WC. Pharmacognosy. 12th ed. English language book society, Bailliere Tindall, London; 1985. p. 394.

15. Subramanian SS, Nagarjan S. Flavonoids of the seeds of Crotolaria retusa and Crotolaria striata. Curr Sci 1969;38:65.

16. Ramawat KG, Merillon JM. Biotechnology: secondary metabolites. Sci Pub Inc; 2000.

17. Tomita H, Uomori A, Minato H. Steroidal sapogenins and sterols in tissue cultures of Dioscorea tokora. Phytochemistry 1970;9:111.

18. Xiao Z, Storms R, Tsang A. A quantitative starch-iodine method for measuring alpha amylase and glucoamylae activities. Anal Biochem 2006;351:146.

19. Miller GL. Use of dinitrosalicylic acid reaent for determination of reducing suger. Anal Chem 199;31:426.

20. Salem MZM, Aly H, Gohar Y, El-sayed AW. Biological activity of extracts from Morus alba (L.), Albizzia lebbeck (L.) Benth. and Casuarinas glauca sieber against the growth of some pathogenic bacteria. Int J Agric Food Res 2013;2 Suppl 1:9-22.

21. Rashid RB, Chowdhury R, Jabbar A, Hasan CM, Rashid MA. Constituents of Albizzia lebbek and antibacterial activity of an isolated flavone derivative. Saudi Pharma J 2003;11:52-6.

22. Kirtikar KR, Basu BD. Indian medicinal plants. Vol. III. Periodical expert book agency, New Delhi, India; 1933.

23. Parotta J. Healing plants of peninsular India, CABI Publication; 2002.

24. Kunyanga CN, Imungi JK, Okoth MW, Biesalski HK, Vadivel V. Total phenolic content, antioxidant and antidiabetic properties of methanolic extract of raw and traditionally processed Kenyan indigenous food ingredients. LWT-Food Sci Technol 2012;45:269-76.

25. Dineshkumar B, Analava M, Manjunatha M. A comparative study of alpha amylase inhibitory activities of common antidiabetic plants of Kharagpur 1 block. Int J Green Pharm 2010;4:115-21.

\section{How to cite this article}

- $\quad$ Priyanka Jaiswal, Padma Kumar. Alpha amylase inhibitory activity of different extract of bark of Albizia lebbeck (L.) benth. Int J Pharm Pharm Sci 2017;9(8): 119-122 